\title{
Analisis Hambatan Belajar (Learning Obstacles) Dalam Pembelajaran Geometri: Literatur Review
}

\author{
Diski Novainda ${ }^{*}$, Turmudi ${ }^{2}$ \\ ${ }^{1,2}$ Universitas Pendidikan Indonesia, Bandung, Jawa Barat 40154, Indonesia
}

Pengiriman: 15/Januari/2021; Diterima: 24/September/2021; Publikasi: 30/September/2021

DOI: https://doi.org/10.31629/jg.v6i2.2866

\begin{abstract}
Abstrak
Penelitian ini bertujuan untuk menginvestigasi dan mengidentifikasi hambatan belajar yang sering terjadi di SMP pada beberapa materi geometri selama lima tahun terakhir. Penelitian ini merupakan studi literatur dengan menganalisis hasil penelitian sebelumnya yang identik. Dengan tahapan yaitu (1) mengidentifikasi artikel-artikel yang mengkaji hambatan belajar pada materi geometri, (2) menganalisis hambatan belajar yang ditemukan dalam mempelajari geometri, (3) mengidentifikasi kesamaan hambatan belajar dari beberapa materi geometri. Berdasarkan enam artikel utama yang di analisis dalam penelitian ini ditemukan beberapa hambatan belajar yang sering muncul pada materi di geometri yaitu: (1) hambatan ontogenik, yaitu kurangnya kemampuan dasar geometri yang dimiliki siswa dan materi yang yang diajarkan tidak disesuaikan dengan kemampuan yang telah dimiliki oleh siswa, (2) hambatan didaktik meliputi (a) materi pada bahan ajar yang tidak di susun dengan benar dan terdapat kesalahan konsep pada bahan ajar yang di gunakan, (b) guru mengajarkan konsep yang tidak sesuai dengan konsep yang seharusnya, (3) hambatan epistemologis yaitu (a) kurangnya materi prasyarat yang telah dimiliki siswa untuk mempelajari materi yang sedang berlangsung, (b) materi yang di ajarkan hanya dari satu konteks, dan tidak dikaitkan dengan beberapa konteks yang berbeda.
\end{abstract}

Kata kunci: hambatan belajar; geometri

\begin{abstract}
This study aims to investigate and identify learning obstacles which frequently occurs in junior high school in terms geometry topics within the last five years. This research is a literature study by analyzing the results of identical previous studies including (1) identifying articles that examine learning obstacles in geometry topics, (2) analyzing learning obstacles found in studying geometry, (3) identifying similar learning obstacles from some geometry topics. Based on the six main articles which analyzed in this study, it was found that there were several learning obstacles that often appeared in geometry topic, namely: (1) ontogenical obstacles, namely the lack of preliminary knowledge of geometry and the topic being taught was not adapted to the abilities that students already had, (2) didactical obstacles consisted of (a) topic on teaching materials that are not arranged properly and there are misconceptions in the teaching materials used, (b) teachers teach concepts that are not in accordance with the respective concept, (3) epistemological obstacles including (a) the lack of students' preliminary knowledge for studying the ongoing topic, (b) the material being taught is only from one context, and did not linked to several different contexts.
\end{abstract}

Keywords: learning obstacles; geometry

*Penulis Korespondensi

Email Address: diskinovianda@upi.edu

Handphone : : +62 85368971403 


\section{JURNAL GANTANG. September 2021; VI(2): 133 - 139 \\ p-ISSN. 2503-0671 \\ e-ISSN. 2548-5547}

\section{Pendahuluan}

Matematika merupakan salah satu pelajaran yang wajib dipelajari oleh siswa saat menempuh jenjang pendidikan di tingkatan sekolah menengah. Matematika merupakan mata pelajaran umum yang harus dipelajari oleh siswa di jenjang SMP dan SMA selain itu matematika juga merupakan salah satu mata pelajaran peminatan untuk siswa yang berada di kelas IPA (Kemendikbud, 2018a, 2018b). Matematika dianggap penting untuk dipelajari oleh setiap orang karena memiliki banyak manfaat baik dalam kehidupan sehari-hari maupun bidang keilmuan lainnya. Seperti pada topik aljabar dapat mendukung banyak pekerjaan dalam bidang keilmuan lainnya seperti jaringan dan komunikasi, hukum fisika, model populasi, dan hasil dari statistik dapat disajikan dalam bentuk simbol-simbol aljabar (NCTM, 2000). Tidak hanya pada topik aljabar, hal yang sama juga berlaku untuk topik lainnya, oleh karena itu matematika merupakan salah satu materi penting untuk dipelajari oleh setiap orang.

Terdapat banyak topik yang dipelajari dalam matematika di Indonesia seperti bilangan, aljabar, geometri dan pengukuran, statistika dan topik-topik lainnya. Salah satu materi yang diajarkan di jenjang sekolah menengah yaitu geometri. Geometri adalah cabang matematika yang mempelajari tentang visualisasi, menghubungkan matematika dengan kehidupan nyata, menggambarkan fenomena yang tidak tampak secara fisik (Usiskin, 1982). Kemudian geometri juga bermanfaat bagi kehidupan seharihari, geometri digunakan untuk memecahkan masalah di bidang lain, baik dalam matematika maupun di luar matematika dan juga dapat digunakan dalam kehidupan (NCTM, 2000). Orang-orang dengan profesi seperti ilmuwan, arsitek, artis, dan insinyur merupakan orangorang yang memanfaatkan konsep geometri untuk pekerjaan mereka (Abdussakir, 2012). Oleh karena itu geometri merupakan suatu materi yang wajib di dalami oleh siswa karena akan memberikan manfaat bagi kehidupan siswa nantinya.
Geometri penting untuk dipelajari oleh siswa, tetapi kemampuan geometri siswa sekolah menengah di Indonesia dapat dikatakan kurang dari ketercapaian yang diharapkan. Seperti yang terlihat pada hasil survei TIMSS (Trends in International Mathematics and Science Study) yang menilai kemampuan matematika siswa di beberapa negara di dunia, dengan beberapa topik yang dinilai termasuk geometri, dengan hasil survei kemampuan matematika siswa usia sekolah menengah Indonesia berada di bawah nilai rata-rata internasional (TIMSS, 2012). Hal yang sama juga ditemukan pada beberapa siswa di salah satu SMP, siswa mengalami kesulitan memahami konsep kubus dan balok, serta kesulitan menemukan dan menggunakan konsep luas permukaan kubus dan balok, hal ini merupakan dampak dari kebiasaan siswa menghafal konsep yang diajarkan (Mutia, 2017). Permasalahan yang sama juga ditemukan di SMP yang berbeda dengan sub-topik yang berbeda, di mana siswa mengalami kesulitan memahami konsep bangun datar, serta tidak dapat membedakan beberapa bangun datar, juga tidak dapat menerapkannya dalam pemecahan masalah (Ma'rifah, Junaedi, \& Mulyono, 2019). Dari beberapa penjelasan tersebut geometri jelas merupakan suatu topik yang penting untuk dikuasai oleh siswa, tetapi kemampuan geometri siswa SMP di Indonesia masih tergolong rendah dan terdapat banyak kesalahan dalam memahami konsep geometri.

Rendahnya kemampuan geometri siswa ini dapat disebabkan oleh banyak faktor, baik dalam pembelajaran maupun faktor dari luar. Salah satunya adalah adanya hambatan belajar selama proses pembelajaran berlangsung. Hambatan merupakan suatu jenis kesulitan belajar karena faktor eksternal yaitu desain didaktis (Suryadi, 2019a). Lebih lanjut hambatan belajar dibagi menjadi tiga, yaitu hambatan ontogenik, hambatan didaktik, dan hambatan epistemologis (Brousseau, 2002; Suryadi, 2019a). Seperti yang terjadi pada salah satu SMP dan SMA di kota Cianjur ditemukan hambatan belajar selama proses pembelajaran topik segitiga 
dan segi empat, seperti kurang luasnya pemberian konsep oleh guru, pemberian masalah dalam pembelajaran hanya dalam bentuk permasalahan rutin, dan juga dari cara mengajar guru yang menugaskan siswa untuk mengapal rumus yang sedang dipelajari yang akan berdampak pada kurangnya pemahaman konsep bagi siswa (Hidayat, Rosjanuardi, \& Juandi, 2019). Hal yang sama juga ditemukan di salah satu SMA di kota Bandung, ditemukan fakta bahwa kurang lengkap dan kesalahan penyajian materi pada buku dan bahan ajar yang digunakan oleh siswa, kurangnya kemampuan prasyarat yang telah dikuasai oleh siswa, pemberian masalah rutin kepada siswa, juga kurangnya aktivitas menemukan konsep yang dilakukan oleh siswa (Setiadi, Suryadi, \& Mulyana, 2017). Masih banyak lagi penelitian terkait hambatan belajar yang telah dilakukan pada jenjang SMP dan menemukan banyak sekali hambatan belajar selama mempelajari geometri dengan materi yang berbeda dalam geometri (Cesaria \& Herman, 2019; Sulistyowati, Budiyono, \& Slamet, 2017; Sunariah \& Mulyana, 2020).

Hambatan belajar ini penting untuk diketahui, karena untuk setiap hambatan belajar yang di temukan dalam pembelajaran nantinya akan dapat di kurangi dengan melakukan kegiatan pembelajaran yang tepat dan dapat di disesuaikan dengan keadaan siswa di kelas. Salah satu pemanfaatan hambatan belajar yaitu dengan mendesain dugaan alur belajar (Hypothetical Learning Trajectory atau HLT) berdasarkan hambatan belajar dan tujuan pembelajaran sebagai acuan dalam proses pembelajaran (Suryadi, 2019b).

Contoh pemanfaatan HLT berdasarkan tujuan pembelajaran, teori van hiele, dan hambatan belajar dilakukan di salah satu sekolah menengah pertama di Palembang pada materi limas, HLT yang didesain dapat mengurangi hambatan belajar yang terjadi selama pembelajaran (Fuadiah \& Sawitri, 2020). Hal yang sama juga ditemukan pada materi dimensi tiga di mana HLT yang dirancang dapat berguna untuk mengatasi hambatan belajar pada topik dimensi tiga (Setiadi, Mulyana, \& Asih, 2019). Hasil analisis hambatan belajar yang diperoleh pada topik tertentu sangat berguna untuk mengurangi hambatan belajar pada topik tersebut.

Mengetahui hambatan belajar dalam pembelajaran sangatlah penting, kemudian setiap topik tentu memiliki hambatan yang berbedabeda dalam mempelajarinya. Apalagi pada topik geometri yang memiliki cakupan yang sangat luas, pada topik geometri terdiri dari dua subtopik utama yaitu bangun datar dan bangun ruang, kemudian sub-topik tersebut dapat dibagi pula menjadi beberapa materi lagi seperti segitiga dan segi empat, kekongruenan, bangun ruang sisi datar, dan beberapa materi lainnya (NCTM, 2000). Seperti pada materi transformasi geometri, keliling dan luas segitiga, bangun ruang sisi datar, dan kekongruenan memiliki beberapa kesamaan dan perbedaan hambatan belajar yang ditemui dalam mempelajarinya (Cesaria \& Herman, 2019; Kusumaningsih, Supandi, \& Ariyanto, 2020; Prayito, 2017; Sunariah \& Mulyana, 2020) .

Oleh karena itu penelitian ini bertujuan untuk menggali dan mengidentifikasi apa saja hambatan belajar yang terjadi di SMP pada beberapa materi geometri. Kemudian berdasarkan latar belakang dan tujuan masalah tersebut hasil penelitian ini dapat bermanfaat untuk digunakan oleh tenaga pendidik sebagai bahan referensi dalam merancang pembelajaran yang dapat mengurangi masalah yang timbul dalam pembelajaran geometri, dengan memanfaatkan informasi tentang hambatan belajar yang sering muncul pada pembelajaran geometri yang merupakan hasil dari penelitian ini. Kemudian hasil penelitian ini juga dapat digunakan sebagai bahan rujukan untuk penelitian lebih lanjut mengenai hambatan belajar siswa pada topik geometri.

\section{Metode Penelitian}

Artikel ini merupakan studi literatur berdasarkan penelitian sebelumnya, tentang hambatan belajar yang ditemukan pada beberapa materi geometri dalam pembelajaran. Kemudian yang menjadi fokus atau objek pada penelitian ini 


\section{JURNAL GANTANG. September 2021; VI(2): 133 - 139 \\ p-ISSN. 2503-0671 \\ e-ISSN. 2548-5547}

adalah hambatan belajar dalam mempelajari geometri. Oleh karena itu penelitian ini bertujuan untuk menginvestigasi dan mengidentifikasi hambatan belajar yang sering terjadi di SMP pada beberapa materi geometri. Literatur yang dipilih adalah beberapa penelitian yang mengungkapkan tentang hambatan belajar di beberapa materi geometri sekolah menengah. Literatur yang dipilih juga merupakan hasil penelitian pada lima tahun terakhir dan merupakan artikel-artikel dari jurnal terindeks baik scopus maupun shinta. Studi literatur ini membandingkan enam literatur utama yang didapat dari google scholar. Literatur utama tersebut merupakan hasil penelitian dari: Sunaryah dan Mulyana tahun 2020, Cesaria dan Herman tahun 2019, Sulisttyowati, dkk tahun 2017, Prayito tahun 2017, Kusumaningsih, dkk tahun 2020, serta Alawiyah, dkk tahun 2018

Studi literatur ini dilakukan melewati beberapa tahapan sebagai berikut: (1) mengidentifikasi artikel-artikel yang mengkaji hambatan belajar pada materi geometri, (2) menganalisis hambatan belajar yang ditemukan dalam mempelajari geometri, (3) mengidentifikasi apa yang kesamaan hambatan belajar dari beberapa materi pada geometri.

\section{Hasil dan Pembahasan}

Merujuk dari literatur pertama yang dianalisis dalam penelitian ini yaitu oleh (Sunariah \& Mulyana, 2020), terdapat beberapa hambatan belajar yang ditemukan pada pembelajaran transformasi geometri di salah satu sekolah menengah meliputi (1) hambatan didaktis yaitu: (a) dalam belajar siswa dan guru lebih mengutamakan pengetahuan prosedural dari pada kemampuan konseptual sehingga dalam menjawab permasalahan yang membutuhkan kemampuan konseptual, siswa tetap mengerjakannya dengan prosedur yang biasa mereka gunakan, (b) sebagai akibat dari poin a, siswa kesulitan mengidentifikasi masalah kontekstual pada materi transformasi geometri, (c) kurang mengetahui tentang karakteristik setiap jenis geometri transformasi, karena siswa diajarkan untuk mengapal bukannya menemukan konsep dalam kegiatan pembelajaran; (2) hambatan epistemologis yaitu: (a) siswa kurang memahami materi sebelumnya yang dibutuhkan untuk mempelajari transformasi geometri, berakibat kepada kesalahan siswa dalam mengaitkan materi sebelumnya dalam memecahkan masalah transformasi geometri, (b) siswa mengalami kesulitan menerapkan pemahaman konsep transformasi geometri ke dalam konteks lainnya, karena siswa dalam kegiatan pembelajaran tidak pernah dihadapkan dengan hal yang demikian.

Selanjutnya berdasarkan literatur kedua (Cesaria \& Herman, 2019), pada materi bangun ruang sisi datar terdapat beberapa hambatan belajar yang ditemui di salah satu sekolah menengah yaitu, (1) hambatan ontogenik, terlihat kurangnya kemampuan dasar geometri siswa, yang mengakibatkan siswa kebingungan saat dihadapkan pada permasalahan bangun ruang sisi datar. (2) Hambatan epistemologis yaitu: (a) siswa dalam kegiatan pembelajaran hanya dihadapkan terhadap satu konteks tertentu saja, sehingga jika dihadapkan dengan konteks yang berbeda siswa mengalami kendala dalam belajar, (b) pengetahuan siswa yang terbatas pada satu konteks tertentu, hal ini dapat disebabkan karena guru hanya memberikan cara atau pengetahuan tunggal saja saat mengerjakan suat konsep, atau karena siswa yang tidak mampu mengikuti apa yang diajarkan oleh guru.

Sedangkan berdasarkan literatur ketiga(Sulistyowati et al., 2017). Terdapat beberapa hambatan belajar yang ditemukan pada pembelajaran volume prisma di salah satu sekolah menengah yaitu, (1) hambatan didaktis, di sekolah tersebut menggunakan buku buku sekolah elektronik (BSE), setelah dilakukan analisis pada buku tersebut ditemukan bahwa dalam mencari volume prisma, buku tersebut langsung menyajikan bentuk prisma yang diperoleh dari membelah suatu balok menjadi dua, hal ini tidak salah tetapi terlalu abstrak untuk dipahami oleh siswa SMP. (2) hambatan epistemologis, di mana guru terbiasa memberikan 
rumus kepada siswa tanpa menjelaskan alur ditemukan rumus, serta kurangnya kegiatan penerapan konsep yang ajarkan dalam berbagai konteks.

Merujuk pada literatur keempat (Prayito, 2017). Ditemukan beberapa hambatan belajar pada materi keliling dan luas segitiga di salah satu sekolah menengah yaitu, (1) hambatan ontogenik, yaitu guru tidak mencari tahu kemampuan apa yang diketahui oleh siswa, pada saat pembelajaran keliling dan volume segitiga materi-materi yang sudah diketahui oleh siswa tetap di ajarkan yang dapat mengakibatkan kurang maksimal pengetahuan yang diterima oleh siswa. (2) hambatan epistemologis, siswa selalu diajarkan dengan konteks segitiga dengan alas bidang yang horizontal, tidak pernah di ajarkan dengan konteks bentuk segitiga yang berbeda, sehingga mengakibatkan siswa kesulitan dalam menentukan mana yang dikatakan garis tinggi segitiga dengan bidang yang tidak horizontal, siswa mengalami kesulitan menentukan luas segitiga dengan konteks yang berbeda, siswa kesulitan menggambarkan objek geometri, serta juga berakibat pada kesulitan bagi siswa untuk untuk membedakan konsep garis tinggi, garis bagi, garis berat, dan garis sumbu.

Merujuk pada literatur (Kusumaningsih et al., 2020). Terdapat beberapa hambatan belajar yang ditemukan pada pembelajar kekongruenan di salah satu sekolah menengah yang meliputi (1) hambatan didaktis, yaitu: (a) karena adanya lembaga belajar di luar sekolah yang mengajarkan konsep yang praktis dengan solusi cepat dalam belajar, yang berakibat pada tidak lengkapnya konsep yang diterima oleh siswa. Hal ini mengharuskan guru mengajarkan konsep yang sebenarnya dalam pembelajaran (b) karena kurang lengkapnya informasi yang diperoleh oleh siswa, berakibat pada siswa mengalami kesulitan dalam memahami perbedaan kongruensi untuk semua jenis segitiga, (c) guru mengajarkan materi kepada siswa sesuai dengan buku yang digunakan di sekolah tersebut, sedangkan pada buku tersebut hanya mengajarkan teori yang baku (2) hambatan epistemologis, yaitu: karena terbiasa diajarkan dengan satu konteks dalam pembelajaran, siswa mengalami kesulitan jika hadapkan dengan permasalahan kekongruenan dengan konteks yang berbeda, Seperti siswa kesulitan membedakan dua benda yang kongruen, dan pada saat diberikan permasalahan kekongruenan pada konteks kehidupan sehari-hari siswa mengalami kesulitan dalam memecahkan masalah tersebut.

Lebih lanjut berdasarkan pada literatur keenam (Alawiyah, Waluya, Priyono, \& Prasetyo, 2018). Terdapat beberapa hambatan belajar (Learning Obstacle) yang ditemukan pada pembelajar luas segi empat di salah satu sekolah menengah yang meliputi (1) hambatan didaktis, yaitu: (a) buku yang digunakan siswa dalam menemukan konsep luas segi empat dengan menyajikan contoh-contoh yang dapat mengarahkan siswa ke rumus luas daerah segi empat, jika diberikan masalah di luar contoh tersebut akan menimbulkan masalah dalam pembelajarannya, (b) terdapat kesalahan konsep yang diterima oleh siswa dalam pembelajaran, seperti untuk menemukan rumus luas jajar genjang, belah ketupat, layang-layang, belah ketupat, dan trapesium dengan menggunakan pendekatan luas persegi. Hal ini tidak berlaku untuk semua jenis jajar genjang, (c) istilah yang digunakan guru dalam pembelajaran kurang jelas, jadi apa yang harus di kerjakan oleh siswa menjadi tidak jelas, (d) urutan materi yang diajarkan yang tidak sesuai dengan seharusnya. Seharusnya segitiga diajarkan sebelum mempelajari segi empat, karena segi empat diperoleh dari menyusun beberapa segitiga. (2) hambatan epistemologis, yaitu: (a) siswa mengalami miskonsepsi dalam penggunaan konsep titik dan garis, dan beberapa siswa juga kesulitan dalam melakukan operasi perkalian dan pembagian, (b) siswa mengalami kendala belajar dalam menggabungkan informasi yang di dapatkan pada soal yang diberikan.

Berdasarkan enam artikel utama yang di analisis dalam penelitian ini, terdapat beberapa hambatan belajar yang ditemukan di beberapa materi geometri. Dari hasil analisis beberapa artikel utama tersebut ditemukan beberapa 


\section{JURNAL GANTANG. September 2021; VI(2): 133 - 139 \\ p-ISSN. 2503-0671 \\ e-ISSN. 2548-5547}

hambatan belajar yang sering muncul di berbagai materi geometri, dapat disimpulkan bahwa (1) hambatan ontogenik yang sering terjadi dalam pembelajaran di beberapa materi geometri yaitu kurangnya kemampuan dasar geometri yang dimiliki siswa dan materi yang diajarkan tidak disesuaikan dengan kemampuan yang telah dimiliki oleh siswa (Sunariah \& Mulyana, 2020)(Prayito, 2017), (2) hambatan didaktik yang sering terjadi dalam pembelajaran di beberapa materi geometri yaitu (a) materi pada bahan ajar yang tidak di susun dengan benar dan terdapat kesalahan konsep pada bahan ajar yang di gunakan (Sulistyowati et al., 2017) (Kusumaningsih et al., 2020)(Alawiyah et al., 2018), (b) guru mengajarkan konsep yang tidak sesuai dengan konsep yang seharusnya (Kusumaningsih et al., 2020)(Alawiyah et al., 2018), (3) hambatan epistemologis yang sering terjadi dalam pembelajaran di beberapa materi geometri yaitu (a) kurangnya materi prasyarat yang telah dimiliki siswa untuk mempelajari materi yang sedang berlangsung (Sunariah \& Mulyana, 2020)(Alawiyah et al., 2018), (b) materi yang di ajarkan hanya dari satu konteks, dan tidak dikaitkan dengan beberapa konteks yang berbeda.

Untuk mengatasi hambatan belajar yang terjadi dalam pembelajaran geometri terdapat banyak solusi yang dapat dilakukan salah satu yang dapat dilakukan untuk kedepannya yaitu dengan menyusun dugaan lintasan belajar (hypotetical learning trajectory) berdasarkan hambatan belajar yang telah ditemukan serta tujuan pembelajaran yang di harapkan pada topik geometri. Agar guru dapat memfasilitasi ragam alur belajar yang berkembang, guru harus dapat memprediksi berbagai kemungkinan respon siswa sebagai akibat situasi didaktis yang dikembangkan sehingga HLT dapat dijadikan acuan utama dalam pembelajaran (Suryadi, 2019b). Jadi oleh karena itu HLT ini dapat dijadikan solusi dalam upaya untuk mengatasi hambatan belajar pada topik geometri.

Seperti yang dijelaskan oleh (Asfyra, 2017) dalam memahami bilangan rasional dari beberapa konteks lintasan belajar (hypotetical learning trajectory) yang didesain dapat membantu siswa dalam memahami konsep. Oleh karena itu diharapkan ada penelitian lanjutan untuk mengembangkan lintasan belajar (hypotetical learning trajectory) berdasarkan hambatan belajar yang telah didapatkan dalam penelitian ini.

\section{Kesimpulan}

Berdasarkan hasil analisis enam artikel yang membahas tentang hambatan belajar (learning obstacles) yang terjadi pada materi geoemetri di sekolah menengah pertama dalam lima tahun terakhir diperoleh bahwa beberapa hambatan belajar yang sering muncul pada materi di geometri yaitu: (1) hambatan ontogenik, yaitu kurangnya kemampuan dasar geometri yang dimiliki siswa juga terdapat materi yang diajarkan tidak disesuaikan dengan kemampuan yang telah dimiliki oleh siswa, (2) hambatan didaktik meliputi (a) materi pada bahan ajar yang tidak di susun dengan benar dan terdapat kesalahan konsep pada bahan ajar yang di gunakan, (b) guru mengajarkan konsep yang tidak sesuai dengan konsep yang seharusnya, (3) hambatan epistemologis yaitu (a) kurangnya materi prasyarat yang telah dimiliki siswa untuk mempelajari materi yang sedang berlangsung, (b) materi yang di ajarkan hanya dari satu konteks, dan tidak dikaitkan dengan beberapa konteks yang berbeda.

\section{Referensi}

Abdussakir, A. (2012). Pembelajaran geometri sesuai teori Van Hiele. Madrasah, 2(1). https://doi.org/10.18860/jt.v2i1.1832

Alawiyah, A., Waluya, S. B., Priyono, A., \& Prasetyo, B. (2018). Didactical situations of students 'mathematical reasoning based on the learning obstacle on quadrilateral areas. Ujmer, 7(1), 196-203.

Asfyra, I. B. (2017). Konteks busana pada pembelajaran operasi bilangan rasional dengan pendekatan PMRI. Jurnal Gantang, 2(1), 11-19. https://doi.org/10.31629/jg.v2i1.61

Brousseau, G. (2002). Theory of didactical situations in mathematics (N. Balacheff, M. Cooper, R. Sutherland, \& V. Warfield, eds.). United States of America: Kluwer 
Academic Publishers.

Cesaria, A., \& Herman, T. (2019). Learning obstacle in geometry. Journal of engineering science and technology, 14(3), 1271-1280.

Fuadiah, N. F., \& Sawitri, Z. A. (2020). A new learning trajectory on the pyramid volume for secondary school. Journal of Physics: Conference $\quad$ Series, $1480(1)$ https://doi.org/10.1088/17426596/1480/1/012028

Hidayat, C. R., Rosjanuardi, R., \& Juandi, D. (2019). Epistemological obstacle on the topic of triangle and quadrilateral. Journal of Physics: Conference Series, 1157(4). https://doi.org/10.1088/17426596/1157/4/042110

Kemendikbud. (2018a). Permendikbud nomor 35 tahun 2018.

Kemendikbud. (2018b). Permendikbud nomor 36 tahun 2018.

Kusumaningsih, W., Supandi, S., \& Ariyanto, L. (2020). Ethnomathematics for congruence concept: A didactical design in a mathematics classroom. Journal of Physics: Conference $\quad$ Series, 1663(1). https://doi.org/10.1088/17426596/1663/1/012036

Ma'rifah, N., Junaedi, I., \& Mulyono. (2019). Tingkat kemampuan berpikir geometri siswa kelas VIII. Prosiding Seminar Nasional Pascasarjana UNNES, 4-7.

Mutia, M. (2017). Analisis kesulitan siswa SMP dalam memahami konsep kubus balok dan alternatif pemecahannya. Beta Jurnal Tadris Matematika, $\quad 10(1), \quad 83$. https://doi.org/10.20414/betajtm.v10i1.107

NCTM. (2000). Principles and standards for school mathematics. United States of America.

Prayito, M. (2017). Learning obstacle on the material circumference and area of triangle in Limpung junior high school number 2 . International Journal of Science and Applied Science: Conference Series, 1(1), 64.

https://doi.org/10.20961/ijsascs.v1i1.5116

Setiadi, D. R., Mulyana, E., \& Asih, E. C. M. (2019). Learning trajectory of three dimensions' topic through analytical geometry approach. Journal of Physics: Conference $\quad$ Series, 1157(3). https://doi.org/10.1088/1742-

6596/1157/3/032109

Setiadi, D. R., Suryadi, D., \& Mulyana, E. (2017). Didactical design enrichment of angle in geometry. Journal of Physics: Conference Series, $895(1)$. https://doi.org/10.1088/17426596/895/1/012060

Sulistyowati, F., Budiyono, \& Slamet, I. (2017). The didactic situation in geometry learning based on analysis of learning obstacles and learning trajectory. AIP Conference Proceedings, 1913. https://doi.org/10.1063/1.5016657

Sunariah, L., \& Mulyana, E. (2020). The didactical and epistemological obstacles on the topic of geometry transformation. Journal of Physics: Conference Series, 1521(3). https://doi.org/10.1088/17426596/1521/3/032089

Suryadi, D. (2019a). Landasan filosofis penelitian Desain Didaktis (DDR). In Landasan Filosofis Penelitian Desain Didaktis (DDR). Bandung: Gapura Press.

Suryadi, D. (2019b). Penelitian Desain Didaktis $(D D R)$ dan implementasinya (1st ed.; A. S. Maulida, ed.). Bandung: Gapura Press.

TIMSS. (2012). Timss 2011 international results in mathematics. In TIMSS \& PIRLS International Study Center (Vol. 2012).

Usiskin, Z. (1982). Van Hiele levels and achievement in secondary school geometry. Chicago: University of Chicago. 